\title{
The Impact of Information Technology on High-Skilled Labor in Services: Evidence from Firm-Level Panel Data ${ }^{1}$
}

\author{
Martin Falk ${ }^{2}$ \\ Katja Seim ${ }^{3}$
}

October 1999, Revised January 2000

\begin{abstract}
This paper analyses the link between the high-skilled employment share and the level of investment in information technology (IT) in the service production process. The analysis is based on an unbalanced panel data set for 933 West German firms over the period 1994-1996. To account for firms which do not employ high-skilled labor, proxied by university graduates, fixed and random effects Tobit models are applied. We investigate whether the importance of IT varies across subsectors by allowing coefficients to differ across the main service sector industries. The empirical evidence indicates that firms with a higher IT investment to output ratio employ a larger fraction of high-skilled workers. However, the size of the IT effect on skill intensity is rather small.
\end{abstract}

Keywords: demand for high-skilled labor, information technology, service sector, panel data

JEL Classification: J23, O33, L8

\footnotetext{
${ }^{1}$ The initial work for this paper was conducted when the second author was a visiting scholar at the ZEW during the summer of 1998. Financial assistance from the ZEW is gratefully acknowledged. The first author acknowledges financial support from the German Science Foundation's program 'Industrial Economics and Input Markets'. The authors would like to thank Thomas Bauer, Badi Baltagi, Herbert Buscher, Francois Laisney, Georg Licht, Joachim Möller, Steve Nickell, and Viktor Steiner for their useful comments. Earlier versions of this paper were presented at the 1999 ZEW Summer School Workshop, the 1999 EALE conference in Regensburg and the 1999 Meetings of the Verein für Sozialpolitik in Mainz. We have greatly benefited from comments received at these conferences.

${ }^{2}$ Centre for European Economic Research, L7,1, D-68161 Mannheim; phone: (0621) 1235-153; fax: (0621) 1235225; e-mail: falk@zew.de

${ }^{3}$ Department of Economics, Yale University, 37 Hillhouse Avenue, New Haven, CT 06520-8264; phone: (203) 432-3577; e-mail: katja.seim@yale.edu
} 


\section{Introduction}

The last decade has witnessed a pronounced shift in labor demand towards high-skilled workers. The changing trends in labor demand are not primarily driven by shifts in economic activity between industry towards more skill-intensive activities, rather they have arisen within most industries, both manufacturing and non-manufacturing industries. The increased demand for skilled labor at the industry level coincides with the spread of information and communication technologies. Complementarity between human capital and information/communication technologies or other new technologies may be one of the factors explaining the rapid intra-industry demand shifts away from unskilled labor and towards skilled labor. It remains unclear, however, how much of the shift in demand towards skilled labor can be explained by the accumulation of information technology.

The increased employment of high-skilled labor may be related to a changing workplace organization marked by, for example, a greater reliance upon computers and other communication technologies in which a different set of skills is required. Some authors, such as Robinson and Manacorda (1997) and Büchel and Weißhuhn (1997), however, claim that the increased employment of highskilled workers solely reflects the rapid growth in educational levels and attainment of the work force. When choosing from a growing body of university graduates, firms may be able to employ a rising fraction of high-skilled workers to occupy jobs for which they are overqualified. The increasing shares of high-skilled workers among firms' work forces would then be solely a supply side phenomenon whereby a larger body of well educated candidates chases a fixed pool of highskilled jobs. ${ }^{1}$ Calculations based on the German Socio-Economic Panel (GSOEP) show, however, that the proportion of under-utilized university graduates has been very stable over the period 1984 to 1997, amounting to approximately $25 \%$ each year. This evidence then suggests that rising educational attainment per se is not a sufficient explanation for the trend to employ increasing shares of high-skilled workers. Instead there may be some fundamental changes in the production process of certain sectors that justify the need for a more educated work force.

The link between information/communication capital and the skill structure of the labor force has been empirically analyzed by a number of authors (for a survey of the literature, see Chennells and Van Reenen 1999). Several studies based on US firm level data show that the greater use of information technology or advanced technologies is associated with a larger employment share of highly educated workers, at least in manufacturing industries (Doms et al. 1997 and Bresnahan et al. 1999).

Very little empirical evidence is available, however, on the importance of information technology in the service sector. Casual evidence suggests, though, that for skill-intensive service industries such as consulting or business services, information technology is a crucial part of the production process. This paper attempts to provide some insights into these issues by investigating the impact of information technology on the high-skilled employment share of service sector firms. The study is based on data drawn from the first two waves of the Mannheim Service Innovation Panel (MIP-S) which has previously been analyzed by Kaiser (1999). Our estimates of the determinants of the demand for university graduates are based on an unbalanced panel data set of 933 West German firms for the period between 1994 and 1996. We separately investigate the role of IT in four service subsectors: (i) wholesale and retail trade and transport, (ii) banking and insurance, (iii) software, data processing, technical consultancy and business services, and (iv) other business services and waste disposal.

Interestingly, one third of all firms do not employ any university graduates. Approximately $15 \%$

\footnotetext{
${ }^{1}$ Thanks go to Thomas Bauer, IZA, for pointing out this potential explanation.
} 
of the firms employ neither university graduates, masters, nor technicians. To control for the censoring of the high-skilled labor share as well as unobservable effects, we employ panel Tobit models. We use both the fixed effects Tobit models suggested by Honoré (1992) and the standard random effects Tobit models. Moreover, we employ random effects panel Probit models to explain a firm's decision to employ university graduates. Population-averaged models estimated by General Estimating Equation techniques (GEE) are used to specify the panel's within-group correlation structure. Moreover, shift share analyses based on the German Labor Force survey investigate the within contribution of the shift away from unskilled and towards skilled labor. Following Maurin and Thesmar (1999), we use an extended shift share analysis to allow for functional diversity within sectors and to thereby analyze the role of organizational change. Based on the estimated firm-level elasticities, we quantify how much of the aggregate skill-upgrading within the service sector can be explained by IT accumulation.

The layout of the paper is as follows. Section 2 outlines the econometric model. Data for the study are discussed in section 3. In section 4, we present the results for the factor demand equations. Section 5 provides a shift share analysis based on industry-level data using the German Labor Force Survey. Section 6 concludes.

\section{Empirical Modelling}

\subsection{Employment share equation}

To investigate the link between information technology and the skill intensity of the firm, we employ factor demand equations. Under constant returns to scale and under the absence of substitution possibilities between different labor inputs, a quasi-fixed translog cost function with three types of variable factors (high-skilled labor $H$, medium-skilled labor $M$ and unskilled labor $U$ ) and two quasi-fixed factors (physical capital $K$ and IT capital IT) implies the following cost share for high-skilled labor, $s_{H}$ :

$$
s_{H}=\alpha_{H}+\beta_{1} \ln I T+\beta_{2} \ln K+\beta_{3} \ln Q+\sum_{i=H, U} \beta_{i} \ln \left(w_{i} / w_{M}\right)
$$

where $w$ denote factor prices and $Q$ plant output (see Chennels and Van Reenen 1999). Since wages by skill class are generally not available at the firm level, one can employ the skill-specific employment shares to proxy the unknown cost shares. To account for the large share of firms that report zero expenditures for IT or non-IT investment, we use the level of the capital to output ratios and their squares instead of the common logarithmic specification. The high-skilled employment share of firm $i$ operating in industry $j$ at time $t$ is then given by:

$$
E H_{i t}=\alpha_{i}+\beta_{1 j} I T Q_{i t}+\beta_{2 j} I T Q_{i t}^{2}+\beta_{3 j} K Q_{i t}+\beta_{4 j} K Q_{i t}^{2}+\beta_{n j} z_{i t}+u_{i t}
$$

The variables are defined as: 


$\begin{array}{ll}E H & \text { high-skilled employment share (censored) } \\ \text { ITQ } & \begin{array}{l}\text { information technology and communication } \\ \text { capital as \% of output }\end{array} \\ K Q & \text { physical capital as \% of output } \\ z & 1, \ldots, 4 \text { firm size classes } \\ & \text { participation in R\&D and exporting } \\ & \text { part of industrial conglomerate }\end{array}$

Complementarity between IT capital and high-skilled labor would imply a strong positive correlation between the IT output ratio and the high-skilled employment share $\left(\partial E H_{i t} / \partial I T Q_{i t}>0\right)$. A positive effect of the investment to output ratio on the high-skilled employment share would indicate, on the other hand, that capital is a complement to skilled labor. The data used in this study contains detailed information on an employee's educational attainment which we use to proxy her unobserved inherent skill. The primary measure of high-skilled labor used in the following results is based solely on educational achievement and denotes all employees with a completed university degree in any subject as high-skilled. To investigate the robustness of this measure, we also constructed an alternative measure of high-skilled labor which includes masters and technicians and thus reflects that skill can be accumulated through either education or on-the-job training. The results based on the second measure of high-skilled labor did not differ significantly from the ones based on university graduates only. We include several firm characteristics in the share equation to control for observable factors which may make high-skilled labor more productive for some firms than for others. These dummies indicate a firm's size, its export orientation, participation in R\&D activities, as well as whether the firm is part of a larger industrial conglomerate. Export orientation represents a particularly valuable control variable because the exporting activity of German firms is concentrated in skill-intensive goods and services.

The particular characteristics of the dataset call for slight modifications of the above specification. The MIP-S dataset does not include measures of the book value of capital or past investment flows for IT and non-IT expenditures, but only current IT and non-IT investment measured in nominal prices. We therefore use investment flows as proxies for the IT and non-IT capital stocks. Some justification for this choice of proxies is provided by the following evidence. German national accounts provide information on the investment expenditure as well as the overall net capital stock for 13 West German service industries (wholesale and retail trade, banking, insurance, railways, water transport, real estate, education and social services, and other services including business services). In a descriptive regression using 1994 industry data, we find a strong, positive relationship between the net capital stock to value added ratio measured at constant prices each and the investment to value added ratio in nominal prices. The Pearson correlation coefficient is 0.91 (pvalue 0.001 ). Accounting for different sector sizes by using value added as weights results in an even larger correlation coefficient of about 0.99 (p-value 0.001). The relationship between the investment output ratio and the capital stock output ratio proves stable when the time series dimension is taken into account. A two-way fixed effects regression for the period between 1975 and 1994 yields:

$$
\begin{aligned}
& \frac{K_{i t}^{c p}}{V A_{i t}^{c p}}=\underset{(6.9)}{2.98} \frac{I N V_{i t}}{V A_{i t}}+f(\text { industry and time dumies }) \\
& \text { adj. } \mathrm{R}^{2}=0.99, \text { obs. }=13 \times 20
\end{aligned}
$$

where $I N V_{i t}$ denotes total investment in sector $i$ in year $t$ in current prices, $V A_{i t}^{c p}, V A_{i t}$ value added in constant and nominal prices, respectively, and $K_{i t}^{c p}$ the net capital stock in constant 
prices. The strong relationship between the capital output ratio and the investment output ratio based on within sector as well as cross-sectional estimation provides some justification for the use of the flow value of investment as a proxy of the underlying, unobserved capital stock. In addition, assuming a constant, time-invariant relationship between IT expenditures and total investment, the current period IT expenditure may be used to proxy the underlying IT capital stock. Current IT expenditures may be very close to the discounted value of accumulated past IT investments due to the high rate of depreciation of computer and information technologies.

\subsection{Estimation techniques}

The techniques chosen for the econometric estimation of the high-skilled share equation (1) reflect the censored nature of the dependent variable. A substantial fraction of firms, approximately $32 \%$ of all respondents in the data set, does not employ high-skilled labor in the form of university graduates. $^{2}$ Standard least squares panel techniques do not take this selection problem into account. The literature has suggested several extensions of the cross-sectional Tobit model to address censoring for the case of panel data, including random-effects Tobit models and semi-parametric fixed effects models. Alternatively, the decision to employ high-skilled labor can be analyzed separately from the decision over how much high-skilled labor to employ by using Panel Probit or double hurdle models. The individual models will be presented briefly in the following sections.

The cross sectional Tobit model can be readily extended to the random effects panel framework (see Maddala 1987). The true underlying dependent variable, $y^{*}$, is a function of a set of independent variables, $x$, as well as a random effect, $u_{i}$ :

$$
y_{i t}^{*}=\beta^{\prime} x_{i t}+u_{i}+\nu_{i t} \quad \nu_{i t}, u_{i} \sim N\left(0,0, \sigma_{v}^{2}, \sigma_{u}^{2}\right)
$$

while the actually observed value of the dependent variable, $y$, is given by:

$$
y_{i t}= \begin{cases}L & y_{i t}^{*} \leq L \\ y_{i t}^{*}=\beta^{\prime} x_{i t}+u_{i}+\nu_{i t} & L<y_{i t}^{*}\end{cases}
$$

and is only observed for those values of $y^{*}$ that exceed the lower censoring bound, $L$. The panel Tobit model also includes time effects, which are common to all firms. If both the residuals, $\nu_{i t}$, as well as the random effect, $u_{i}$, are normally distributed, equation (2) can be estimated by maximum likelihood using Gaussian quadrature methods to evaluate the product of the standard normal density functions. Gaussian quadrature yields unreliable results, however, in the face of high within correlation or non-normality of the disturbances $v_{i t}$. In the present application, the employment decision may well be highly correlated over time within any given firm, questioning some of the assumptions of the random effects model.

The semi-parametric fixed effects Tobit estimator put forth by Honoré (1992) avoids some of the strong distributional assumptions of the random effects Tobit model. This approach is an extension of Powell's $(1984,1986)$ work on cross-sectional censored least absolute deviation estimators

\footnotetext{
${ }^{2}$ Approximately $15 \%$ of all respondents do not employ either university graduates or masters and technicians. Less than $1 \%$, however, report a university graduate share equal to 1 . Therefore, censoring in the upper tail of the distribution is not taken into consideration.
} 
(CLAD) and symmetrically trimmed least squares estimators (STLS). The error term, $v_{i t}$, is assumed to be independent and identically distributed conditional on the $x_{i t}$ and the $u_{i}$ for all $t$. The assumption that the errors are uncorrelated over time implies that any two observations of the latent variable for a given firm $i,\left(Y_{i s}^{*}, Y_{i t}^{*}\right)$, are distributed symmetrically around the $45^{\circ}$ line through $\left(X_{i s}^{\prime} \beta, X_{i t}^{\prime} \beta\right)$ or alternatively through $\left(\left(X_{i t}-X_{i s}\right)^{\prime} \beta, 0\right)$ for any given $u_{i}$ such that the probabilities of observing a value for $\left(Y_{i s}^{*}, Y_{i t}^{*}\right)$ above or below the dividing line are equal. Honoré exploits this symmetry in the distribution of the latent variable to construct a moment condition which must hold at the true values of the parameters:

$$
E\left[\xi\left(\max \left\{y_{i t}, \delta\right\}-\max \left\{y_{i s}, \delta\right\}-\delta\right) \Delta x_{i}\right]=0
$$

where $\delta=\left(x_{i t}-x_{i s}\right)^{\prime} \beta$ and $\xi$ denotes any increasing function with $\xi(0)=0$ and antiderivative $\Xi$. These orthogonality conditions are the asymptotic first order conditions for the minimization of the sample analog of the objective function used to define the estimators:

$$
\widehat{\beta}=\arg \min \sum_{i=1}^{n} s\left(y_{i t}, y_{i s}, \delta\right)
$$

where

$$
s\left(y_{i s}, y_{i t}, \delta\right)= \begin{cases}\Xi\left(y_{i s}\right)-\left(y_{i t}+\delta\right) \xi\left(y_{i s}\right) & \delta \leq-y_{i t} \\ \Xi\left(y_{i s}-y_{i t}-\delta\right) & -y_{i t}<\delta<y_{i s} \\ \Xi\left(-y_{i t}\right)+\left(y_{i s}-\delta\right) \xi\left(-y_{i t}\right) & y_{i s} \leq \delta\end{cases}
$$

Since the estimated coefficients, $\widehat{\beta}$, are to some degree sensitive to the choice of loss function, $\Xi$, we present results for the minimization of the symmetric distance function using a quadratic loss function, $\Xi(d)=d^{2}$, as well as a polynomial loss function, $\Xi(d)=d+d^{2}+d^{3}$ which is more robust to outliers (see Campbell and Honoré 1991). While the fixed effects estimator is robust to heteroscedasticity of the error terms, the asymptotic variance covariance matrix of $\widehat{\beta}$ can only be consistently estimated for a large number of firms $(i \geq 200)$.

A more general alternative to the above described Tobit estimators are double-hurdle or generalized Tobit models which separate the firm's discrete decision to employ high-skilled labor per se and the subsequent decision of how much high-skilled labor to employ (see Labeaga 1999 for an application of panel double-hurdle models to smoking). The first stage in the firm's decision making process models the decision to employ high-skilled labor as a univariate, random effects panel Probit model:

$$
\begin{aligned}
& y_{i t}^{*} \quad=\beta^{\prime} x_{i t}+\varepsilon_{i t} \\
& y_{i t}= \begin{cases}1 & y_{i t}^{*}>0 \\
0 & \text { otherwise }\end{cases} \\
& \varepsilon_{i t} \quad=u_{i}+\nu_{i t} \\
& E\left(\varepsilon_{i s}, \varepsilon_{j t}\right)= \begin{cases}\sigma_{u}+\sigma_{v} & i=j, s=t \\
\sigma_{u} & i=j, s \neq t \\
0 & i \neq j\end{cases}
\end{aligned}
$$

where $u_{i}$ again denotes the individual firm effect and $\nu_{i t}$ the random error. The assumption that the firm effect $u_{i}$ is independent of the observable $x_{i t}$ for all $i$ and $t$ produces a consistent estimator, 
however, similar problems to the ones described above in the case of the random effects Tobit model arise in the presence of high within-firm correlation (high value of $\rho$ ). ${ }^{3}$

As an alternative population averaged models (Liang and Zeger 1986) may be employed which can accommodate potential within firm correlation in the error term. Generalized linear models do not fully specify the distribution of the population, but instead describe it solely by its marginal distribution. Standard discrete choice population averaged models assume that the individual firm observations $y_{i t}$ are independent Bernoulli trials with an expected value $E\left(y_{i t}\right)$ equal to the probability that the event will occur, $p$, and a variance $\operatorname{Var}\left(y_{i t}\right)$ equal to $p(1-p)$. In the case of the Probit model, $p$ is assumed to be distributed standard normal:

$$
\begin{aligned}
& E\left(y_{i t}\right) \quad=\operatorname{Pr}\left(y_{i t}=1 \mid x_{i t}\right) \quad=\Phi\left(x_{i t}^{\prime} \beta\right) \quad=\mu_{i t} \\
& \operatorname{Var}\left(y_{i t} \mid x_{i t}\right)=E\left(y_{i t}\right)\left(1-E\left(y_{i t}\right)\right)=\Phi\left(x_{i t}^{\prime} \beta\right) \cdot\left(1-\Phi\left(x_{i t}^{\prime} \beta\right)\right)=\sigma_{i t}^{2}
\end{aligned}
$$

where $\Phi$ denotes the standard normal distribution function and $\beta$ the parameter vector to be estimated. Let $\mu_{i}=E\left(Y_{i}\right)=\left\{\mu_{i 1}, \ldots, \mu_{i T}\right\}^{\prime}$ and $A_{i}=\operatorname{diag}\left\{\sigma_{i 1}^{2}, \ldots, \sigma_{i T}^{2}\right\}$. The parameter vector $\beta$ is estimated by minimizing in $\beta$ the standard distance criterion function which yields the general estimating equation as its first order condition:

$$
U(\beta)=\sum_{i=1}^{K} \frac{\partial \mu_{i}^{\prime}}{\partial \beta} V_{i}^{-1}\left(Y_{i}-\mu_{i}\right)=0
$$

$V_{i}$ denotes the variance covariance matrix across time for a given firm $i$. In the case of independent observations, $V_{i}$ simply equals $A_{i}$. The principal difference to the standard random effects Probit model is that the parameter vector $\beta$ describes an average population response rather than an individual response to a change in $x$. This means, for example, that under a population averaged model, the average exporting firm employing high-skilled labor is compared to the average nonexporting firm employing high-skilled labor. The main advantage of population averaged models is that they allow us to specify the within-group correlation structure by relaxing the assumption of independence of the Bernoulli trials for a given firm across time. Assuming an AR(1) structure would result in an error correlation matrix of the following form:

$$
R_{i}(\rho)= \begin{cases}1 & \text { if } \mathrm{t}=\mathrm{s} \\ \rho^{|t-s|} & \text { otherwise }\end{cases}
$$

where $R_{i}$ denotes the working correlation matrix for firm $i$ with a serial correlation coefficient $\rho$ which diminishes as the lag increases. In this case, the variance covariance matrix becomes $V_{i}=$ $A_{i}^{1 / 2} R_{i}(\rho) A_{i}^{1 / 2}$ and equation (7) can be solved by an iterative numerical minimization procedure.

The main advantage of the above specified Probit models in the current context are that the factors influencing a firm's decision of employing any university graduates are allowed to differ from the determinants driving the firm's decision of how many university graduates to employ. One important disadvantage of the two-part modeling, however, is presented by the fact that university graduates make up an essential part of the production process in skill intensive service industries

\footnotetext{
${ }^{3}$ For an application, see Butler and Moffitt (1992). High within correlation also poses a problem for reliable estimation of fixed effects conditional logit models.
} 
such as computing, banking, or R\&D laboratories, and cannot be replaced by less qualified workers. These firms, therefore, do not face the decision of whether or not to employ any university graduates, rather they only decide how many high-skilled workers to employ. This logic suggests that the employment decision making process is not uniform across all service firms engaging in activities as varied as retail trade and $\mathrm{R} \& \mathrm{D}$. To address some of these concerns, we estimate both panel Tobit models and panel Probit models.

\section{Data description}

The data set employed for the subsequent empirical analysis contains the first two waves of Mannheim Service Innovation panel 1995 and 1997 (MIP-S) covering the period 1994-1996. The survey aims to investigate the innovation behavior of service firms (for details see Janz and Licht 1999). Approximately 2550 and 2220 firms, respectively, participated in the first two waves of MIP-S from which we removed East German firms. Since the second wave contains retrospective information for some continuous variables, an unbalanced panel consisting of three years can be constructed. The key variables covered by the study are total output (total sales and total wage bill), different types of investment, the educational qualification structure of the work force, $R \& D$ expenditures as well as R\&D staff and a large number of qualitative variables. Since value added is not available, we use the firm's total wage bill as a proxy which, in the case of the service sector, more closely reflects value added movements than total sales. The original data base distinguishes between five educational qualifications, including two types of university graduates. The first group consists of employees having attained a university degree in engineering or natural science and the second group contains graduates with a degree in social sciences or other fields. Following Kaiser (1999), the engineering/natural science and the social science groups are combined into a single category of university graduates. Two measures of the high-skilled labor share can be constructed. The first high-skilled employment share measures the share of university educated employees out of total employees. The second measure extends this definition to also include masters and technicians. Each high-skilled share is expressed as that group's share of total employees, that is the sum of employees across all five skill groups. IT is defined as investment in information and communication technology and includes expenditures on computers, peripheral equipment, and software. Total gross investment is also provided. In order to avoid double counting, we subtract IT investment from total investment to obtain non-IT investment. ${ }^{4}$

The initial sample for West German firms contains 4428 observations on 2460 firms. For the empirical analysis, we use a reduced sample of firms for which all variables are available. Incomplete information on gross investment, IT investment, employees by skill class, or firm characteristics led to a reduction of the sample to 3353 observations. Exclusion of firms which belong to either the manufacturing or construction sectors reduces the sample by another 23 observations. Furthermore, some 50 obvious typing errors were corrected. Extreme values in the growth rates of the number of employees, total sales per employee and total wage bill per employee in excess of $300 \%$ have been dropped. Observations were also excluded when the ratio of total investment to total labor costs exceeded 300\%. In total, 212 observations were dropped on the basis of the chosen selection criteria. From a total of 2962 observations an unbalanced sample of 1762 West German firms remained. To be able to employ panel data techniques, we furthermore restricted the sample to firms for which two firm year observations were available leaving us with 2193 observations on 933 firms. While the

\footnotetext{
${ }^{4}$ In some cases, firms report positive IT expenditures, but zero total investment expenditures such that IT expenditures exceed total investment expenditures. In these cases, the resulting negative non-IT investment has been replaced by zero.
} 
loss in observations was large, Table 1 shows that most variables (IT output ratio or high-skilled employment share) have distributions that are very similar across the two samples.

Table 1: Summary Statistics, MIP-S 1994-96, West German firms

\begin{tabular}{|c|c|c|c|c|c|c|}
\hline & \multicolumn{6}{|c|}{ Means in \% } \\
\hline & \multicolumn{3}{|c|}{ full sample } & \multicolumn{3}{|c|}{ restricted sample } \\
\hline & '94 & '95 & '96 & '94 & '95 & '96 \\
\hline University graduates share & 14.4 & 14.5 & 15.2 & $\overline{14.9}$ & 14.4 & 14.9 \\
\hline Masters/technicians share & 11.5 & 11.1 & 11.5 & 12.0 & 10.8 & 11.3 \\
\hline Non-IT investment to sales & 5.2 & 5.0 & 4.5 & 5.1 & 5.0 & 4.5 \\
\hline IT investment to sales & 1.1 & 1.1 & 1.3 & 1.2 & 1.1 & 1.2 \\
\hline Non-IT investment to wage bill & 21.5 & 22.0 & 19.6 & 20.9 & 21.9 & 19.6 \\
\hline IT investment to wage bill & 4.6 & 3.9 & 4.2 & 4.2 & 3.7 & 4.2 \\
\hline Exporters & 23.8 & 23.9 & 26.5 & 22.6 & 22.7 & 26.4 \\
\hline $\mathrm{R} \& \mathrm{D}$ activities & 17.8 & 12.4 & 12.5 & 20.3 & 12.5 & 12.5 \\
\hline Part of indust & 36.4 & 35.2 & 36.4 & 28.4 & 35.8 & 36.0 \\
\hline$L<10$ & 12.9 & 15.3 & 14.4 & 13.8 & 14.7 & 14.3 \\
\hline $10 \leq L<20$ & 19.9 & 18.6 & 19.1 & 23.8 & 18.6 & 18.6 \\
\hline $20 \leq L<50$ & 19.7 & 21.4 & 20.8 & 24.1 & 21.2 & 21.0 \\
\hline $50 \leq L<250$ & 25.5 & 27.4 & 27.7 & 23.8 & 27.7 & 28.0 \\
\hline$L \geq 250$ & 21.9 & 17.3 & 18.0 & 14.6 & 17.7 & 18.2 \\
\hline Observations & 1054 & 946 & 962 & 349 & 919 & 925 \\
\hline \multicolumn{7}{|c|}{$\begin{array}{l}\text { Notes: The means given in the table are arithmetic means. Employment } \\
\text { shares are computed as the percent share of university graduates or masters } \\
\text { and technicans of total employment summed across the five educational } \\
\text { qualification groups. }\end{array}$} \\
\hline ource: Mannheim Service Innov & $\mathrm{Pa}$ & 199 & 997. & & ation & \\
\hline
\end{tabular}

Table 1 reports averages of the key variables for the subsample used in the estimation as well as the full sample as a reference. For the restricted sample, firms report that on average $15 \%$ of their employees have obtained a university or higher technical college degree. The masters and technicians' employment share averages to about $11 \%$ which is slightly below that group's corresponding share in the German Labor Force Survey. The restricted sample's combined highskilled labor share (masters and technicians as well as university graduates) amounts to $26.7 \%$ in 1996 and 25.6\% in 1995. Firms have been divided into five size classes based on their total number of employees: the reference group has less than 10 employees, the three medium-sized classes are defined as 10-19, 20-49, and 50-249 employees, while large firms are defined to have more than 250 employees. The share of firms with less than 10 workers ranges from 13\% in 1994 to $15 \%$ in 1996. Over the period between 1994 and 1996, 36\% of West German firms in the sample belonged to a corporate group. The share of exporting firms ranges from 23 to $26 \%$. The percentage of R\&D engaging firms varies between $20 \%$ in 1994 and $13 \%$ in 1996, suggesting that the sample's composition is changing over time.

The service sector is broken down into 10 subsectors. These subsectors do not fully correspond to the NACE 2 digit classification. Some regrouping of industries was found to be necessary and sectors with a large number of firms such as market services were split up into computer, related software and data processing (NACE 72); R\&D labs and technical consultants (NACE 731, 742, 743); business consultants, legal services, and accounting (NACE 741); and other business activities 
including cleaning and advertising (NACE 744-746, 748). To examine the representativeness of the MIP-S survey participants, the sectoral employment distribution in the 1995 wave of the German Labor Force Survey ('Micro Census'), a survey at the level of the individual, was examined by computing sectoral weighted averages across participants employed in the service industries. A comparison of the Micro Census' and the MIP-S' employment distribution reveals that the MIP-S sample is somewhat skewed towards firms in the following sectors: (1) software and data processing, (2) wholesale trade, (3) transport and communication, (4) real estate and renting, as well as (5) banking and insurance.

Table 2 presents a sectoral breakdown of the high-skilled employment share, IT investment output ratio, non-IT investment output ratio, and the participation in exporting and R\&D. The service sector can be differentiated on the basis of the activities' knowledge intensity (measured as an industry's share of workers with completed higher education out of total workers). The most skill-intensive sectors are computer, software and data processing, R\&D laboratories and technical consultants, as well as business services (consultants, legal services, accounting). In these sectors, the share of university graduates lies between $30 \%$ and $45 \%$. Banking and insurance, real estate, and waste disposal can be classified as medium-skill-intensive industries. Finally, wholesale and retail trade, transport, and other business services (cleaning, advertising) can be classified as low-skillintensive. Wholesale and retail trade and other business service activities tend to occupy primarily medium- and unskilled labor. The sectoral breakdown reveals that software and data processing, R\&D labs, and banking and insurance possess the expected higher IT intensity than the remaining sectors. A comparison of the high-skilled labor share and IT investment to sales ratio provides informal evidence that the sectors which are skill-intensive are the ones that use IT intensively. Participation in exports is highest in (1) wholesale trade, (2) R\&D labs and technical consultants, (3) computer, software and data processing and (4) transport and communication. Furthermore, as expected, participation in R\&D is more pronounced in skill-intensive industries. In computer, software and data processing, and in R\&D labs, the percentage of observations with one or more R\&D employees is $40 \%$ and $30 \%$, respectively. Table 2 also indicates that the percentage of firms with zero reported university graduates ranges from $4 \%$ for technical consultants to $54 \%$ for retail trade.

To investigate the sample's representativeness of the German service sector as a whole, the average high-skilled employment share has been compared to 1995 data derived from the German Labor Force Survey ('Micro Census'). A comparison of the university graduates employment share at the sectoral level indicates that the MIP-S sample very closely reflects the Micro Census' national averages. In skill intensive service industries such as software design and data processing, technical consultants and business services, the university employment share ranges between $34 \%$ and $44 \%$, comparable to the $34 \%$ and $43 \%$ shares revealed by the German Labor Force Survey. Across sectors, however, the share of masters and technicians in the MIP-S firm data set considerably exceeds the corresponding figures in the German Micro Census. 
Table 2: Summary Statistics: University graduates share, IT and non-IT wage bill ratios, participation in exports and R\&D by sector

\begin{tabular}{|c|c|c|c|c|c|c|}
\hline & \multirow{2}{*}{$\begin{array}{l}\text { Univers. } \\
\text { grad. } \\
\text { share }\end{array}$} & \multirow{2}{*}{$\begin{array}{l}\text { IT inv. } \\
\text { to wage } \\
\text { bill }\end{array}$} & \multirow{2}{*}{$\begin{array}{l}\text { Non-IT inv. } \\
\text { to wage } \\
\text { bill }\end{array}$} & \multicolumn{2}{|c|}{ Participation (\%) } & \multirow[t]{2}{*}{ Cases } \\
\hline & & & & Export & $\mathrm{R} \& \mathrm{D}$ & \\
\hline & \multicolumn{6}{|c|}{ "Means (in \%, 1994-96) } \\
\hline Wholesale trade & 8.7 & 2.7 & 18.1 & 40.3 & 13.5 & 325 \\
\hline Retail trade and repairs & 4.1 & 2.1 & 20.8 & 17.7 & 5.1 & 311 \\
\hline Transport & 3.7 & 2.5 & 35.4 & 33.1 & 12.6 & 302 \\
\hline Banking, insurance & 13.6 & 7.4 & 12.6 & 12.2 & 8.9 & 304 \\
\hline Real estate & 8.5 & 3.5 & 78.7 & 8.7 & 1.7 & 115 \\
\hline Software, data process. & 41.1 & 7.8 & 7.6 & 33.9 & 36.8 & 174 \\
\hline R\&D labs & 42.5 & 4.2 & 10.1 & 36.8 & 29.2 & 144 \\
\hline Business services & 33.6 & 4.4 & 5.9 & 22.0 & 20.2 & 173 \\
\hline Other business svcs. & 5.9 & 2.9 & 7.1 & 13.5 & 10.2 & 266 \\
\hline Waste disposal & 16.2 & 4.3 & 50.5 & 16.5 & 8.9 & 79 \\
\hline \multirow[t]{2}{*}{ All service sectors } & 14.7 & 3.3 & 15.2 & 15.8 & 11.1 & 2193 \\
\hline & \multicolumn{6}{|c|}{ Zero values (in \%, 1994-96) } \\
\hline Wholesale trade & 36.3 & 17.8 & 20.0 & & & 325 \\
\hline Retail trade and repairs & 54.0 & 20.9 & 20.9 & & & 311 \\
\hline Transport & 47.0 & 15.6 & 15.6 & & & 302 \\
\hline Banking, insurance & 23.4 & 5.9 & 20.1 & & & 304 \\
\hline Real estate & 39.1 & 10.4 & 21.7 & & & 115 \\
\hline Software, data process. & 7.5 & 3.4 & 28.2 & & & 174 \\
\hline $\mathrm{R} \& \mathrm{D}$ labs & 4.2 & 3.5 & 20.8 & & & 144 \\
\hline Business services & 10.4 & 6.4 & 19.1 & & & 173 \\
\hline Other business svcs & 38.0 & 19.5 & 29.3 & & & 266 \\
\hline Waste disposal & 19.0 & 6.3 & 8.9 & & & 79 \\
\hline All service sectors & 31.8 & 12.7 & 20.9 & & & 2193 \\
\hline \multicolumn{7}{|c|}{$\begin{array}{l}\text { Notes: Export } t_{t}=1 \text { if firm has earned positive revenues from exports in } t=1994 \text {, } \\
95 \text { or } 96 \text {. Missing values in } 1995 \text { have been replaced when export information } \\
\text { is available for } 1994 \text { and } 1996 . \mathrm{R} \& D=1 \text { if firm employs at least one } R \& D \\
\text { worker. }\end{array}$} \\
\hline
\end{tabular}

\section{Determinants of the Demand for High-Skilled Labor}

\subsection{Panel Tobit Results for all Service Industries}

Table 3 shows the results for the fixed and random effects panel Tobit models. For the fixed effects Tobit model two specifications are used: the estimated coefficients in column (i) are based on a quadratic loss function while the results displayed in column (ii) use a polynomial loss function. Columns (iii) and (iv) contain the results from a random effects Tobit model. Since time effects are not significant at the $5 \%$ level they have been omitted. The coefficients of the random effects model are based on a 12 point Hermite Gaussian integration and should be interpreted with caution. Refitting the panel Tobit model with a 16 point Hermite integration yielded a change in the coefficient of IT investment output ratio of $9 \%$ while the effect of its square changed by nearly 
17\%. These inconsistencies in the random effects results are clearly related to the high within correlation coefficient $(\rho=0.90)$ causing the quadrature approximations to be inaccurate. ${ }^{5}$ The random effects model does allow, however, for the inclusion of time-invariant variables. The coefficient on the exporter dummy indicates that exporting firms use more skill-intensive labor than their counterparts. This finding is consistent with our conjecture that exporting firms concentrate extensively on human-capital-intensive products relative to firms that do not engage in exporting activities. A firm's R\&D activities may also induce it to employ a more skilled labor force as the positive coefficient on $R \& D$ shows.

Table 3: Fixed and Random effects Tobit models for the $E H$-share

\begin{tabular}{|c|c|c|c|c|c|c|c|c|}
\hline & \multicolumn{4}{|c|}{ FE Tobit } & \multicolumn{4}{|c|}{ RE Tobit } \\
\hline & \multirow{2}{*}{\multicolumn{2}{|c|}{$\begin{array}{l}\text { Quadratic } \\
\text { Loss function }\end{array}$}} & \multirow{2}{*}{\multicolumn{2}{|c|}{$\begin{array}{l}\text { Polynomial } \\
\text { Loss function }\end{array}$}} & \multirow[b]{3}{*}{ coeff } & \multirow[b]{3}{*}{ t-stat } & \multirow[b]{3}{*}{ coeff } & \multirow[b]{3}{*}{ t-stat } \\
\hline & & & & & & & & \\
\hline & coeff & t-stat & coeff & t-stat & & & & \\
\hline ITQ & 0.26 & 1.85 & 0.18 & 1.56 & 0.52 & 7.70 & 0.43 & 6.27 \\
\hline $\mathrm{ITQ}^{2}$ & -0.21 & -1.35 & -0.12 & -0.96 & -0.45 & -4.44 & -0.33 & -3.09 \\
\hline IQ & -0.003 & -0.23 & 0.010 & 0.27 & -0.002 & 0.17 & 0.002 & 0.24 \\
\hline $\mathrm{IQ}^{2}$ & 0.000 & 0.45 & 0.002 & 0.04 & 0.000 & 0.36 & -0.001 & -0.30 \\
\hline Exporters & & & & & & & 0.02 & 3.21 \\
\hline Ind. Congl. & & & & & & & -0.00 & -0.56 \\
\hline $\mathrm{R} \& \mathrm{D}$ & & & & & & & 0.04 & 5.05 \\
\hline $10 \leq L<20$ & & & & & & & 0.00 & -0.58 \\
\hline $20 \leq L<50$ & & & & & & & -0.03 & -2.11 \\
\hline $50 \leq L<250$ & & & & & & & -0.03 & -2.03 \\
\hline$L \geq 250$ & & & & & & & -0.04 & -2.30 \\
\hline Ind. dummies & & & & & $\mathrm{n}$ & & & \\
\hline Constant & & & & & 0.12 & 25.64 & 0.13 & 8.18 \\
\hline Wald tests: & & & & & & & & \\
\hline $\mathrm{ITQ}=\mathrm{ITQ}^{2}=0$ & 4 . & & & & 87 & & & \\
\hline ITQ, ITQ ${ }^{2}$, & & & & & & & & \\
\hline $\mathrm{IQ}, \mathrm{IQ}^{2}=0$ & 7 . & & & & 88 & & & \\
\hline$\rho$ & & & & & 0. & & & \\
\hline$\varepsilon_{E H, I T Q}$ & 0.0 & & & & 0.0 & & & \\
\hline$\varepsilon_{E H, I Q}$ & & & & & 0.0 & & & \\
\hline Obs/firms & 2193 & 933 & 219 & /933 & 2193 & 933 & 219 & 933 \\
\hline $\begin{array}{l}\text { Notes: West } \mathrm{G} \\
\text { Dependent vari } \\
\text { for the Tobit } \mathrm{m} \\
\text { see equation }(9)\end{array}$ & $\begin{array}{l}\text { rman Ser } \\
\text { de: unive } \\
\text { dels: } 697\end{array}$ & $\begin{array}{l}\text { ice firm } \\
\text { sity gra } \\
\text { left-cens }\end{array}$ & $\begin{array}{l}\text { for the } \\
\text { uates en } \\
\text { red obse }\end{array}$ & $\begin{array}{l}\text { period } \\
\text { oloymen } \\
\text { vation }\end{array}$ & $\begin{array}{l}\text { etween } 19 \\
\text { share. O } \\
\text { th } \mathrm{EH}=\end{array}$ & $\begin{array}{ll}94 & \text { and } \\
\text { os. } & \text { sum } \\
0 . & \varepsilon_{E H}\end{array}$ & $\begin{array}{l}996 . \\
\text { lary } \\
T Q:\end{array}$ & \\
\hline
\end{tabular}

For the fixed effects Tobit model based on a quadratic loss function, the Wald test $\left(\chi^{2}(2)=4.7\right)$ indicates that the IT investment output ratio and its square are jointly significant at the $10 \%$ level. We again find a concave quadratic relationship between IT investment output ratio and the university graduates employment share. The predicted high-skilled labor share reaches a maximum

\footnotetext{
${ }^{5}$ Future work will investigate alternative methods such as Simpson's rule to approximating the value of the integral or alternative methods to estimating the random effects Tobit model. Potential solutions include simulated maximum likelihood techniques as proposed by Hajivassiliou (1993).
} 
at an IT investment wage bill ratio of more than $60 \%$ for specification (i) and $75 \%$ for specification (ii), well above the mean IT investment wage bill ratio of $4.0 \%$. The quantitative impact of the IT investment output ratio on the university graduates share, however, is very low. The elasticity of the university graduates share with respect to the IT expenditure output ratio can be calculated as follows: 6

$$
\varepsilon_{E H, I T Q}=S F \times \beta_{1} \overline{I T Q}+S F \times 2 \times \beta_{2} \times \overline{I T Q} / \overline{E H}
$$

where $\beta_{1}$ denotes the estimated IT coefficient and $\beta_{2}$ the one on its square. $\overline{I T Q}$ and $\overline{E H}$ are the sample means of the IT output ratio and the university graduates share. The scale factor, $S F$, can be used to convert coefficients into marginal effects. For the fixed effects panel Tobit model, the scale factor is unknown. Given the pooled Tobit's scale factor of 0.66, relative low elasticities ranging from 0.030 to 0.044 - depending on the specification - result. Thus an increase in the IT investment output ratio of $50 \%$ from $4.0 \%$ to $6.0 \%$ would only raise the average firm's high-skilled labor share by 0.03 percentage points from $14.7 \%$ to $15.0 \%$. Unreported results show that in the presence of firm-specific effects, the pooled Tobit model introduces an upward bias into the estimated IT-coefficients with an estimated IT coefficient of 0.77 and a coefficient of -0.46 on the square of the IT output ratio. The coefficients translate into an IT elasticity of 0.13 which is significantly higher than the IT elasticity based on the fixed effects Tobit model.

As stated in section 2 one important problem with the empirical implementation of the employment share equation is the use of flows as proxies for capital stocks. The use of first differences may reduce the problem of measuring the capital stock. Applying first differences, the change in the skilled employment share can be modeled as a function of the change in the capital output ratio of both types of capital and a vector of $z$ variables (see Chennells and Van Reenen 1999) ${ }^{7}$ :

$$
\Delta E H_{i t}=f\left(\Delta \ln \left(K_{i t}^{c p} / V A_{i t}^{c p}\right), \Delta \ln \left(C_{i t}^{c p} / V A_{i t}^{c p}\right), \ln z\right)
$$

where $K_{i t}^{c p} / V A_{i t}^{c p}$ denotes the firms net capital stock output ratio, $C_{i t}^{c p} / V A_{i t}^{c p}$ the computer capital stock and $z$ contains the exporting, $\mathrm{R} \& \mathrm{D}$ and industrial group firm characteristic dummies, $E X$, $R \& D$, and $C O N C$. In the absence of data on capital stocks, Berman, Bound, and Griliches (1994) propose to proxy the change in the $\mathrm{R} \& \mathrm{D}$ capital stock output ratio by the cross-sectional variation in the initial R\&D sales ratio. We adopt a similar strategy by replacing $\Delta \ln \left(K_{i t}^{c p} / V A_{i t}^{c p}\right)$ and $\Delta \ln \left(C_{i t}^{c p} / V A_{i t}^{c p}\right)$ by the initial, i.e. lagged, IT and non IT investment output ratios. Pooled Tobit MLE of the change in the high-skilled share produces the following results:

$$
\begin{aligned}
& \Delta E H_{i t}=\underset{(2.86)}{0.14} I T Q_{i t-1}+\underset{(0.37)}{0.002} I Q_{i t-1}+\underset{(0.35)}{0.003} E X_{i t}+\underset{(3.11)}{0.031} R \& D_{i t}+\underset{(2.54)}{0.018} C O N C_{i t} \\
& \text { Obs }=1254, \text { coefficients on sector and size dummies omitted. }
\end{aligned}
$$

In comparison, pooled Tobit MLE estimation of the high-skilled employment share yields:

\footnotetext{
${ }^{6}$ Note that, in a censored regression model, the magnitude of the coefficients is not interpretable as the marginal effect of changes in the regressors on the observed dependent variable. Marginal effects are obtained by scaling the parameters by the probability of falling in the uncensored region.

${ }^{7}$ The original specification in Chennels and Van Reenen (1999) distinguishes between R\&D capital and non-R\&D capital. In the present application, IT plays the role of R\&D.
} 


$$
\begin{aligned}
& E H_{i t}=\underset{(5.26)}{0.53} I T Q_{i t-1} \underset{(-0.03)}{-0.004} I Q_{i t-1}+\underset{(3.40)}{0.055} E X_{i t}+\underset{(7.56)}{0.154} R \& D_{i t}+\underset{(3.51)}{0.050} C O N C_{i t} \\
& \text { Obs }=1254, \text { coefficients on sector and size dummies omitted. }
\end{aligned}
$$

These results show that the effect of IT remains significant when the change in the high-skilled share is used as dependent variable. However, the sample size is significantly reduced from 2193 to 1254 observations. In addition, the size of the IT coefficient becomes considerably smaller possibly due to the presence of outliers which will have a much more prominent effect on first-difference estimates (Griliches and Hausman 1986).

\subsection{Panel Probit Results for all Service Industries}

We also use Panel Probit models to identify factors which influence the decision of whether or not to employ university graduates. As noted earlier, approximately one third of the firms in our estimation sample do not employ university graduates and $14.7 \%$ of firms employ neither university graduates nor masters and technicians. Table A1 in the Appendix shows the results for the panel Probit random effects model, where column (i) contains the results for the panel Probit random effects model estimated by population-averaged methods and the specification in column (ii) allows for a first-order autoregressive correlation coefficient. Both specifications' t-statistics are based on robust standard errors.

The results show that the decision over the employment of university graduates is affected by its IT-investment ratio as well as individual firm characteristics (exporting and R\&D activities, firm size and sector). A Wald test supports the hypothesis that the effect of the IT investment output ratio and its square are jointly significantly different from zero. However, we cannot reject the hypothesis that the effect of non-IT investment is significantly different from zero. Moreover, the consistently positive sign of the IT investment output ratio combined with the negative sign on its square across both specifications indicates a concave relationship between the IT investment wage bill ratio and the probability of employing high-skilled labor. The probability of employing university graduates is increasing in the IT output ratio and peaks at an IT investment output ratio of over $100 \%$. The coefficients on firm size are positive and significant at the 5\%-level, suggesting that larger firms requiring the coverage of a larger spectrum of tasks have a higher probability of employing university graduates. Exporting and $R \& D$ activities also contribute to a higher probability of employing university graduates. The coefficients on the industry effects are as expected with a higher probability of employing high-skilled labor being associated with R\&D labs, technical consultants followed by computer and software design as well as business services.

Some additional sensitivity checks are presented. The first point concerns the measurement of the IT investment output ratio. Unreported regression results indicate that employing sales as a measure of value added when computing the investment sales ratios does not alter the results significantly. A second sensitivity test addresses the definition of the dependent variable. As it is unclear which employees a firm would consider to be highly skilled based on their educational record, we investigate the robustness of our results using a broader definition of high-skilled labor which in addition to university graduates includes masters and technicians as well. Re-estimating the panel Probit model using the broader definition of high-skilled labor yields a similar concave relationship between the decision to employ high-skilled labor and the IT investment output ratio. 


\subsection{Differences among Sectors}

In order to account for differences in the service production process as well as differences in the employment decision making process, we reestimate the panel Tobit models for four broad subsectors. The top panel of Table 4 shows the results for wholesale and retail trade and transport. The lower panel shows the results for banking and insurance. The coefficients of primary interest are those on the IT investment output ratios which show a consistent, significant relationship between the share of university graduates and the IT investment output ratio. Wald tests support the hypothesis that the effects of the IT investment sales ratio and its square are jointly different from zero. For the polynomial loss function, for example, the Wald statistic is 5.6 in the case of wholesale, retail trade and transport and 4.7 in the case of banking, insurance, and real estate. The corresponding p-values are 0.06 and 0.097 , respectively. To compare the IT effect across sectors, the scaling factor of the pooled Tobit model is used to convert the IT coefficients into marginal effects. The magnitude of the IT elasticity is found to be substantially larger in banking and insurance with $\varepsilon_{E H, I T Q}=0.13$, more than twice the elasticity based on all service industries. For skill intensive service industries, a consistently low value is found for the IT elasticity across both fixed effects models. ${ }^{8}$

To check the robustness of the results for skill intensive service industries, we exclude firms reporting a zero university graduates share and relate the logarithm of the university graduates share to the IT output ratio and its square. In skill intensive services such as software and data processing, technical consultancy and business services, less than $8 \%$ of the firms report a zero university graduates employment share. Excluding observations with a zero university graduates employment share reduces the estimation sample from 491 to 455 observations.

\footnotetext{
${ }^{8}$ Panel Tobit results with fixed and random effects for the skill intensive service industries are available from the authors on request.
} 
Table 4: Fixed and Random effects Tobit models for the $E H$-share, subgroups

\begin{tabular}{|c|c|c|c|c|c|c|}
\hline & \multicolumn{4}{|c|}{ FE Tobit } & \multirow{2}{*}{\multicolumn{2}{|c|}{$\begin{array}{l}\text { RE Tobit } \\
\text { (iii) }\end{array}$}} \\
\hline & \multicolumn{2}{|c|}{ (i) } & \multicolumn{2}{|c|}{ (ii) } & & \\
\hline & coeff & t-stat & coeff & t-stat & coeff & t-stat \\
\hline \multicolumn{7}{|c|}{ Wholesale and retail trade, transport } \\
\hline ITQ & 0.21 & 1.12 & 0.25 & 1.80 & 0.50 & 4.41 \\
\hline $\mathrm{ITQ}^{2}$ & -0.43 & -1.12 & -0.56 & -2.26 & -0.84 & -3.69 \\
\hline $\mathrm{IQ}^{2}$ & 0.004 & 0.12 & 0.02 & 0.70 & 0.01 & 0.79 \\
\hline $\mathrm{IQ}^{2}$ & 0.00 & 0.05 & 0.00 & -0.35 & 0.00 & -0.82 \\
\hline Exporter & & & & & 0.02 & 1.92 \\
\hline Ind. congl. & & & & & 0.09 & 9.62 \\
\hline $\mathrm{R} \& \mathrm{D}$ & & & & & 0.04 & 4.13 \\
\hline Constant & & & & & -0.03 & -2.01 \\
\hline $\mathrm{ITQ}=\mathrm{ITQ}^{2}=0$ & \multicolumn{2}{|c|}{1.6} & \multicolumn{2}{|c|}{5.6} & \multicolumn{2}{|c|}{19.44} \\
\hline $\mathrm{ITQ}=\mathrm{ITQ}^{2}=\mathrm{IQ}=\mathrm{IQ}^{2}=0$ & \multicolumn{2}{|c|}{1.8} & \multicolumn{2}{|c|}{6.1} & \multicolumn{2}{|c|}{20.85} \\
\hline$\partial \mathrm{EH} / \partial \mathrm{ITQ} \cdot \overline{I T Q} / \overline{E H}$ & \multicolumn{2}{|c|}{0.039} & \multicolumn{2}{|c|}{0.047} & \multicolumn{2}{|c|}{0.096} \\
\hline$\partial \mathrm{EH} / \partial \mathrm{IQ} \cdot \overline{I Q} / \overline{E H}$ & \multicolumn{2}{|c|}{0.014} & \multicolumn{2}{|c|}{0.033} & \multicolumn{2}{|c|}{0.023} \\
\hline Obs/firms & \multicolumn{2}{|c|}{$938 / 397$} & \multicolumn{2}{|c|}{$938 / 397$} & \multicolumn{2}{|c|}{$938 / 397$} \\
\hline \multicolumn{7}{|c|}{ Banking and insurance, real estate } \\
\hline ITQ & 0.40 & 1.86 & 0.35 & 1.92 & 0.37 & 3.39 \\
\hline $\mathrm{ITQ}^{2}$ & -0.29 & -1.48 & -0.26 & -1.60 & -0.22 & -1.76 \\
\hline IQ & 0.00 & 0.03 & 0.002 & -0.10 & 0.04 & 2.49 \\
\hline $\mathrm{IQ}^{2}$ & 0.00 & 0.10 & 0.00 & 0.24 & 0.00 & -1.71 \\
\hline Exporter & & & & & 0.00 & -0.11 \\
\hline Ind. group & & & & & 0.09 & 5.80 \\
\hline $\mathrm{R} \& \mathrm{D}$ & & & & & -0.03 & -1.65 \\
\hline Constant & & & & & 0.01 & 0.67 \\
\hline $\mathrm{ITQ}=\mathrm{ITQ}^{2}=0$ & \multicolumn{2}{|c|}{4.8} & \multicolumn{2}{|c|}{4.7} & \multicolumn{2}{|c|}{19.12} \\
\hline $\mathrm{ITQ}=\mathrm{ITQ}^{2}=\mathrm{IQ}=\mathrm{IQ}^{2}=0$ & \multicolumn{2}{|c|}{7.5} & \multicolumn{2}{|c|}{8.1} & \multicolumn{2}{|c|}{21.75} \\
\hline$\partial \mathrm{EH} / \partial \mathrm{ITQ} \cdot \overline{I T Q} / \overline{E H}$ & \multicolumn{2}{|c|}{0.132} & \multicolumn{2}{|c|}{0.116} & \multicolumn{2}{|c|}{0.125} \\
\hline$\partial \mathrm{EH} / \partial \mathrm{IQ} \cdot \overline{I Q} / \overline{E H}$ & 0.0 & & 0.0 & & & \\
\hline Obs/firms & $419 /$ & 175 & $419 /$ & 175 & 419 & 175 \\
\hline
\end{tabular}

Notes: see table 3. Specification (i) uses a quadratic, (ii) a polynomial loss function. The number of left-censored observations with $\mathrm{EH}=0$ are 428 and 116, respectively. The scale factors of 0.48 and 0.71 , respectively, are based on the pooled tobit model. The random effects specification includes both industry and size dummies. The within correlation coefficients are 0.86 and 0.85 , respectively. 
Table 5 shows the results for the determinants of the log university graduates employment share based on the restricted sample. Since the IT output ratio and the IT output ratio squared are not significant at the five percent level, we only include the IT output ratio. Column (i) shows the results for the fixed effects models. Columns (ii) and (iii) show the results for the random effects models, whereby specification (ii) assumes a constant within correlation coefficient of the residuals and the specification in column (iii) relaxes this assumption by specifying the within-group correlation as an AR (1) process. The random effects model allowing for an AR(1) process of the residuals is estimated by population-averaged models and t-statistics are based on robust standard errors. Both random effects models include sector dummy variables for software and technical consultants. The Hausman test statistic indicates that the random effects estimator seems to be the appropriate model to estimate the determinants of the log high-skilled employment share.

Table 5: Fixed and Random effects models for the log $E H$-share Subgroups: software, data processing, R\&D labs and business services

\begin{tabular}{|c|c|c|c|c|c|c|}
\hline & \multicolumn{2}{|c|}{$\mathrm{FE}$} & \multicolumn{2}{|c|}{$\mathrm{RE}$} & \multicolumn{2}{|c|}{$\mathrm{RE}, \mathrm{AR}(1)$} \\
\hline & coeff & t-stat & coeff & t-stat & coeff & t-stat \\
\hline ITQ & 0.67 & 1.97 & 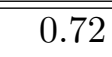 & 2.13 & "0.72 & 2.25 \\
\hline ITQ $\times$ software & -0.94 & -1.68 & -0.88 & -1.59 & -0.70 & -1.40 \\
\hline IQ & 0.11 & 0.37 & -0.03 & -0.11 & 0.09 & 0.62 \\
\hline $\mathrm{IQ} \times$ business svcs & -0.47 & -1.37 & -0.33 & -1.06 & -0.44 & -2.46 \\
\hline Exporter & & & 0.16 & 2.19 & 0.14 & 1.62 \\
\hline Ind. cong. & & & -0.26 & -1.70 & -0.28 & -1.69 \\
\hline $\mathrm{R} \& \mathrm{D}$ & & & 0.17 & 2.46 & 0.13 & 1.11 \\
\hline $10 \leq \mathrm{L}<20$ & & & -0.16 & -1.54 & -0.16 & -2.50 \\
\hline $20 \leq \mathrm{L}<50$ & & & -0.05 & -0.37 & -0.04 & -0.41 \\
\hline $50 \leq \mathrm{L}<250$ & & & -0.14 & -0.96 & -0.11 & -0.90 \\
\hline $\mathrm{L} \geq 250$ & & & -0.61 & -2.71 & -0.61 & -2.32 \\
\hline Software & & & 0.13 & 0.72 & 0.12 & 0.65 \\
\hline Tech. consultants & & & 0.28 & 1.62 & 0.28 & 1.59 \\
\hline $\mathrm{d}_{95}$ & 0.08 & 2.17 & 0.09 & 2.33 & 0.09 & 1.41 \\
\hline $\mathrm{d}_{96}$ & 0.12 & 3.26 & 0.12 & 3.26 & 0.13 & 2.00 \\
\hline Constant & -1.32 & -35.08 & -1.33 & -8.20 & -1.33 & -8.13 \\
\hline Hausman test & & & & & & \\
\hline$\rho ; \rho_{1} / \rho_{2}$ & & & & & 0.96 & 0.93 \\
\hline$\partial \mathrm{EH} / \partial \mathrm{ITQ} \cdot \overline{I T Q} / \overline{E H}$ & & & & & & \\
\hline Obs/firms & 44 & 192 & 445 & 192 & 445 & \\
\hline
\end{tabular}

Notes: Dependent variable: logarithm of the university graduates employment share. Hausman test: To compare the RE and FE models, time-invariant variables are not included in the RE model. Critical value for the Hausman test is $\chi^{2}[4] .95=9.49 . \quad \rho$ denotes the within correlation coefficient of the residuals obtained from the standard linear random effects model while $\rho_{1}$ and $\rho_{2}$ denote the within correlation coefficient of the residuals (1994-95, 1995-96) obtained from the population-averaged model.

The significant relationship between the log share of university graduates and the IT investment sales ratio results in similarly low IT elasticity across both random and fixed effects models. The 
random effects IT coefficient of 0.72 translates into an IT elasticity of high-skilled labor of $0.04 \% .^{9}$ The more flexible specification allowing for an AR (1) error structure yields an IT elasticity of $0.057 \%$. Thus an increase in the IT investment to output ratio by $50 \%$ (from $5.7 \%$ to $8.6 \%$ ) would only raise the firm's high-skilled employment labor share by approximately one percentage point from $42.0 \%$ to $42.9 \%$. For the one third of firms which export over the period 1994-96, we find that exporting reinforces the positive relationship found between IT investment and the employment of high-skilled labor.

\section{Determinants of the shift in skill structure}

\subsection{Within versus between industry shifts}

The previous analysis has solely focused on the demand for high-skilled labor within the unit of the firm. It is conceivable, however, that much of the increase in demand for high-skilled labor can be attributed to employment shifts away from low skill-intensive industries to high-skill intensive industries, thus to shifts across firms rather than within firms. A standard way to evaluate effects of changes in the industrial structure on the composition of the work force is to decompose the overall change in the composition into changes that occurred between industries and those that occurred within industries. Since the time period of the firm-level data set covers only 3 years, the shift-share analysis is carried out using data on three educational qualification classes drawn from the German Labor Force Survey and the Employment Register of the Federal Labor Office. Following the framework used by Berman, Bound and Griliches (1994) the change in the aggregate high-skilled employment share can be written as:

$$
\Delta \frac{L_{H t}}{L_{t}}=\sum_{s=1}^{S} \Delta\left(\frac{L_{s t}}{L_{t}}\right) \cdot \frac{\overline{L_{H s t}}}{L_{s t}}+\sum_{s=1}^{S} \frac{\overline{L_{s t}}}{L_{t}} \Delta\left(\frac{L_{H s t}}{L_{s t}}\right)
$$

where $s=1, \ldots, S$ denotes sectors, $L_{H}$ high-skilled labor, and $L$ the total labor force. A bar denotes the variable's mean over time. $\frac{L_{H s t}}{L_{s t}}$ measures the share of high-skilled workers in an industry, $\Delta \frac{L_{H t}}{L_{t}}$ is the change in the high-skilled employment share in the economy as a whole and $\frac{L_{s t}}{L_{t}}$ is the sectoral employment share. The above equation thus decomposes the change in the high-skilled employment share into two effects. The first term measures the contribution resulting from employment shifts between sectors of different skill intensity. If there is a substantial reallocation of high-skilled labor to skill-intensive sectors, this effect should be large. The second term measures the contribution to total change resulting from the shift towards skilled workers within a sector.

Table 6 lays out the result of this decomposition for three different types of labor using two different data sources, the Micro Census and the Employment Register of the Federal Labor Office. For the latter, we also report results for two different time periods. The last column shows the within shift as a proportion of the total change. For university graduates, $71 \%$ of the total 2.2 percentage point increase can be attributed to within industry changes during the period between 1991 and 1995 . Thus, nearly all industries have experienced increases in the share of university graduates. The corresponding figure for workers with vocational degrees and workers without any formal degree is $53 \%$ and $84 \%$, respectively. A similar picture holds true for the United States and United Kingdom (Berman et al. 1994, Autor et al. 1998, Machin and Van Reenen 1998), where the between effect also accounts for a very small part of the overall shift.

\footnotetext{
${ }^{9}$ The IT-impact evaluated at sample means is $0.72 \times 0.057=0.04$, where 0.057 is the sample mean for the IT output ratio based on the restricted sample in skill intensive services (software, technical consultancy, business services).
} 
Table 6: Decomposition analysis of the change in the employment shares of different educational classes

\begin{tabular}{|c|c|c|c|c|c|c|c|c|}
\hline & \multirow{2}{*}{\multicolumn{2}{|c|}{$\begin{array}{c}\text { employees } \\
(000 \mathrm{~s}) \\
\end{array}$}} & \multirow{2}{*}{\multicolumn{2}{|c|}{$\begin{array}{c}\text { employment } \\
\text { share }(\%) \\
\end{array}$}} & \multicolumn{3}{|c|}{ change (percentage points) } & \multirow{2}{*}{$\begin{array}{c}\text { within } \\
\text { change }(\%)\end{array}$} \\
\hline & & & & & total & between & within & \\
\hline \multicolumn{9}{|c|}{ Based on Micro Census (sectors=20), private sector,1991-95 } \\
\hline \multirow{4}{*}{$\begin{array}{l}\text { unskilled } \\
\text { voc. school } \\
\text { univer. grad. }\end{array}$} & 1991 & 1995 & 1991 & 1995 & $95 / 91$ & $95 / 91$ & $95 / 91$ & $95 / 91$ \\
\hline & 4412 & 4345 & 19.3 & 17.8 & -1.4 & -0.3 & -1.1 & 81.6 \\
\hline & 15875 & 16656 & 69.3 & 68.4 & -0.8 & -0.4 & -0.4 & 52.8 \\
\hline & 2619 & 3343 & 11.4 & 13.7 & 2.2 & 0.6 & 1.5 & 70.7 \\
\hline
\end{tabular}

Based on employment statistics (sectors $=269$ ), private sector,1991-95

\begin{tabular}{lrrrrrrrr}
\hline & 1991 & 1995 & 1991 & 1995 & $95 / 91$ & \multicolumn{1}{c}{$95 / 91$} & $95 / 91$ & \multicolumn{1}{c}{$95 / 91$} \\
\cline { 2 - 8 } unskilled & 5288 & 4375 & 27.1 & 23.3 & -3.7 & -0.6 & -3.2 & 84.8 \\
voc. school & 13088 & 13060 & 67.0 & 69.6 & 2.7 & 0.4 & 2.2 & 84.3 \\
univer. grad. & 1167 & 1322 & 6.0 & 7.0 & 1.1 & 0.1 & 0.9 & 86.2 \\
\hline
\end{tabular}

Based on employment statistics (sectors $=269$ ), private sector, 1978-96

\begin{tabular}{lrrrrrrrr}
\hline & 1978 & 1996 & 1978 & 1996 & $96 / 78$ & \multicolumn{1}{c}{$96 / 78$} & \multicolumn{1}{c}{$96 / 78$} & \multicolumn{1}{c}{$96 / 78$} \\
\cline { 2 - 8 } unskilled & 6097 & 4163 & 36.0 & 22.6 & -13.4 & -1.6 & -11.8 & 87.9 \\
voc. school & 10221 & 12925 & 60.3 & 70.0 & 9.7 & 1.0 & 8.7 & 89.6 \\
univer. grad. & 631 & 1371 & 3.7 & 7.4 & 3.7 & 0.6 & 3.1 & 83.5 \\
\hline
\end{tabular}

Notes: For the Micro Census, the number of workers with missing skill information ranges from $5 \%$ in 1991 to $9 \%$ in 1995, while the corresponding numbers for the employment statistics are 1260 cases in 1978 and 1660 cases in 1996.

Source: Federal Employment Office, own calculations.

Based on the social security statistics, the contribution of the within component is somewhat higher. For 269 West German industries for the 1991-95 period, 86\% of the change in employment share of university graduates share can be attributed to within industry shifts. For the longer period between 1978 and 1996 the within component accounts for 84\% of the rise in the high-skilled labor share. The results for the shift-share analysis based on the social security statistics should be interpreted with caution, though. Since self-employed workers and workers who earn less than a minimum wage threshold are not covered by this data base, services such as advertising, cleaning etc. which were categorized as other services above are substantially underrepresented. ${ }^{10}$

\subsection{Role of organizational change}

The shift towards university graduates can be attributed to shifts within a given service sector industry, to shifts between two service sector industries, but also to shifts within the firm itself away from production activities towards service activities. We examine whether the shift in demand towards high-skilled labor is uniform across all fields/activities and how much of the skill-upgrading is attributable to industry change as well as organizational change by employing an industryorganization matrix. An additional layer of disaggregation is added by assigning firms to industrial sectors and by separating the processes undertaken by the firm into three activities: production,

\footnotetext{
${ }^{10}$ For instance, the social security statistics underestimate the number of workers by $10 \%$ in legal, accounting, and consultancy firms (NACE 741) as well as industrial cleaning (NACE 747). In advertising (NACE 744), the two data sources differ by $30 \%$.
} 
service activities and research and development. Service activities are further divided into sales, clerical and other service activities. Table A2 in the Appendix documents the shift away from unskilled production activities towards service activities over time. In manufacturing, employment directly related to production activities accounted for $49.2 \%$ in 1991 and $47.3 \%$ in 1995 . Furthermore, most university graduates are occupied by R\&D and design activities with a share of $35 \%$. In contrast, skill requirements are much lower in production activities as well as sales and repairs. These tasks require only a small numbers of workers with a university degree. The shift towards high-skilled labor is uniform across occupations/fields in both non-manufacturing and manufacturing industries. This contrasts with the results presented by Maurin and Thesmar (1999) who found that the share of skilled workers has remained stable within most occupations/fields.

Following Maurin and Thesmar (1999), the simple shift share analysis is extended to account for the diversity of occupations within sectors:

$$
\Delta \frac{L_{H t}}{L_{t}}=\sum_{s=1}^{S} \Delta\left(\frac{L_{s t}}{L_{t}}\right) \cdot \frac{\overline{L_{H s t}}}{L_{s t}}+\sum_{s, f}^{S} \frac{\overline{L_{s t}}}{L_{t}} \frac{\overline{L_{f H s t}}}{L f_{s t}} \Delta\left(\frac{L_{f s t}}{L_{s t}}\right)+\sum_{s, f}^{S} \frac{\overline{L_{s t}}}{L_{t}} \frac{\overline{L_{f s t}}}{L_{s t}} \Delta\left(\frac{L_{f H s t}}{L f_{s t}}\right)
$$

where $f$ denotes the activities/occupations, $\frac{L_{f H s t}}{L f_{s t}}$ is the high-skilled employment share in each activity within industries, and $\frac{L_{f s t}}{L_{s t}}$ is the activity's employment share within industries. The first component measures the between effect. The second component measures the magnitude of the within sector reallocation. The remaining third component measures the residual within components. Table 7 shows the results for the extended shift-share analysis. For university graduates 0.2 percentage points of the total 2.2 percentage point increase can be attributed to within functional change. Thus, the shift towards more-skilled intensive functions within industries explains only a small part of the shift in demand towards high-skilled labor.

Table 7: Extended shift share analysis allowing for within shifts across occupations

\begin{tabular}{|c|c|c|c|c|c|c|}
\hline & \multicolumn{3}{|c|}{ Unskilled Labor } & \multicolumn{3}{|c|}{ University Graduates } \\
\hline & 1991 & 1995 & $95 / 91$ & 1991 & 1995 & $95 / 91$ \\
\hline Employment share (\%) & 19.3 & 17.8 & & 11.4 & 13.7 & \\
\hline Total change & & & -1.4 & & & 2.2 \\
\hline Between change & & & -0.3 & & & 0.7 \\
\hline Within change across occupations & & & -0.1 & & & 0.2 \\
\hline Residual within change & & & -1.0 & & & 1.4 \\
\hline$\%$ within change & & & 70.2 & & & 62.5 \\
\hline
\end{tabular}

Notes: Unless otherwise noted, change expressed in percentage points.

Source: German labor Force Survey, '91, '93, '95; 70\% sample.

\subsection{Contribution of IT accumulation to skill-upgrading}

To shed some light on the quantitative impact of the estimates, we perform some counterfactual calculations of how much of the aggregate change in the university graduates share during the period between 1991 and 1995 can be explained by IT accumulation. Two scenarios are considered. The first scenario assumes that the change in the IT output ratio amounted to $5 \%$ per year during the period from 1991 to 1995 . This IT accumulation mirrors the $5.3 \%$ overall increase in the per 
capita IT expenditure for the German economy based on EITO figures. ${ }^{11}$ The second scenario assumes that the change in the IT output ratio amounted to $10 \%$ per year.

Table 8: Contribution of IT accumulation to skill upgrading, 1991-95

\begin{tabular}{|c|c|c|c|}
\hline & $\begin{array}{l}\text { Wholesale, retail } \\
\text { trade, transport }\end{array}$ & $\begin{array}{l}\text { Banking \& } \\
\text { insurance }\end{array}$ & $\begin{array}{r}\text { Business } \\
\text { services }\end{array}$ \\
\hline High-skilled employment share, 1991 & 5.0 & 9.8 & 26.7 \\
\hline High-skilled employment share, 1995 & 6.4 & 11.1 & 31.5 \\
\hline$\%$ within change & 3.9 & 2.7 & 2.6 \\
\hline Assumed $\varepsilon_{E H, I T}{ }^{a}$ & 0.039 & 0.132 & 0.030 \\
\hline Impact of $5 \%$ increase in IT on ITQ & 0.2 & 0.7 & 0.2 \\
\hline Impact of $10 \%$ increase in IT on ITQ & 0.4 & 1.4 & 0.3 \\
\hline Impact of $5 \%$ increase in IT on $\mathrm{EH}^{b}$ & 6 & 26 & 6 \\
\hline Impact of $10 \%$ increase in IT on $\mathrm{EH}^{b}$ & 12 & 52 & 12 \\
\hline \multicolumn{4}{|c|}{$\begin{array}{l}\text { Notes: }{ }^{a} \text { for computation of elasticities based on fixed effects Tobit, see table } 4 . \\
b \text { as percent of within change }\end{array}$} \\
\hline Source: German labor Force Survey, '91, ' & ' '95; 70\% sample, & a calculati & \\
\hline
\end{tabular}

Table 8 shows the results of the calculations for three service subsectors: (i) wholesale, retail trade and transport, (ii) banking, insurance and real estate and (iii) software, technical consultancy and business services. The IT elasticities are based on previous, firm-level estimates. Our calculations suggests that in banking and insurance, for the given elasticity, $\varepsilon_{E H, I T}$, and the $5 \%$ increase in the IT ratio, one fourth of the shift in demand towards university graduates can be explained by the IT accumulation. For the skill intensive industries as well as retail and wholesale trade, only $6 \%$ of the increase in the university graduates share can be attributed to IT accumulation.

\section{Conclusions and Extensions}

This paper has presented a number of factor demand models to investigate the link between skill intensity and information technology at the firm level in service industries. Our econometric model allows for censoring at the lower bounds of the employment share as well as for unobserved firm heterogeneity. We also examine the sensitivity of the results with respect to model specification. Most importantly, we find a positive relationship between the share of high-skilled workers and information technology, after controlling for firm size, industry affiliation, other heterogeneity controls and unobserved firm characteristics. Firms with a higher proportion of information technology investment in total output employ more university graduates. However, the size of the IT effect on skill intensity is rather small. A consistently low value is found for the IT elasticity across all models. The magnitude of the IT elasticity is found to be substantially larger in banking and insurance, a sector which may have benefited dramatically from improvements in computing networks, but whose workplace organization may have consequently had to adapt significantly justifying the need for skill upgrading. In the 90's in business industries, $6 \%$ of the within industry skill upgrading can be explained by IT accumulation given the elasticities at the firm level. The corresponding figure for banking and insurance is $25 \%$. A more detailed study of the factors that affect firms' skill

\footnotetext{
${ }^{11}$ According to EITO, the per capita annual IT expenditure increased from 845 to 1,038 ECU from 1991 to 1995 amounting to an average annual growth rate during this period of $5.3 \%$. IT investments as a percent of GDP grew at an annual rate of $2 \%$ over the same period.
} 
structures indicates that firms' export orientation, $R \& D$ activities and ownership characteristics have positive effects on the chosen skill intensity.

Finally, various decomposition analyses are provided based on the German Labor Force Survey. Most importantly, the shift in demand towards high-skilled labor can be explained by within industry shifts as well as by between industry effects rather than by the increasing role of service activities in all sectors of the economy.

In the future, as more waves of the MIP-S data set become available, it will be desirable to estimate a proper dynamic model of the firm's joint decision of its production inputs, IT capital and highskilled labor. At the current time, the short time dimension of the data in this paper renders an estimation of the dynamic decision making process infeasible. 


\section{References}

Autor, H., L. F. Katz and A. B. Krueger (1998). Computing inequality: Have computers changed the labor market. Quarterly Jounal of Economics, 113(4), 1169-1213.

Baltagi, B. H. (1995). Econometric Analysis of Panel Data. Chichestor: John Wiley \& Son Ltd.

Berman, E., J. Bound and Z. Griliches (1994). Changes in the Demand for Skilled Labor within U.S. Manufacturing: Evidence from the Annual Survey of Manufactures. Quarterly Journal of Economics, 109(2), 367-397.

Bresnahan, T., E. Brynjolfsson and L. Hitt (1999). Information Technology, Workplace Organization and the Demand for Skilled Labor: Firm-level Evidence. NBER working paper \# 7136.

Büchel, F. and G. Weißhuhn (1997). Ausbildungsinadäquate Beschäftigung der Absolventen des Bildungssystems: Fortsetzung der Berichterstattung zu Struktur und Entwicklung unterwertiger Beschäftigung in West- und Ostdeutschland. Technische Universität Berlin, Diskussionspapier 3.

Butler, J. S. and R. Moffitt (1982). A computationally Efficient Quadrature Procedure for the One Factor Multinomial Probit Model. Econometrica, 50(3), 761-764.

Campbell, J. and B. E. Honoré (1991). Pantob Instructions, Gauss Program. Princeton University. available at http://webware.princeton.edu/econometrics/programs/pantob/

Chennells, L. and J. Van Reenen (1999). Has Technology hurt less skilled workers? An Econometric Survey of the Effects of Technological Change on the Structure of Pay and Jobs. Institute for Fiscal Studies, London, Working Paper Series No. 99/27.

Doms, M., T. Dunne and K. R. Troske (1997). Workers, wages, and technology. Quarterly Journal of Economics, 112(1), 253-290.

EITO (1998). European Information Technology Observatory. Frankfurt/Main.

Greene, W. (1997). Econometric analysis. Upper Saddle River, NJ: Prentice-Hall.

Griliches, Z. and J. A. Hausman (1986). Errors in Variables in Panel Data. Journal of Econometrics, 31(1), 93-118.

Grootendorst, P. V. (1997). Health Care Policy Evaluation using Longitudinal insurance claims data: An Application of the Panel Tobit estimator. Health Economics, 6, 365-382.

Haijvassiliou, V. A. (1993). A Simulation Estimation Analysis of the External Debt Crises of Developing Countries. London School of Economics.

available at http://econ.lse.ac.uk/staff/vassilis/

Honoré, B. E. (1992). Trimmed LAD and least squares estimation of truncated and censored regression models with fixed effects. Econometrica, 60, 533-65.

Janz, N. and G. Licht (1999), Innovationsaktivitäten in der deutschen Wirtschaft - Analyse der Mannheimer Innovationspanels im Verarbeitenden Gewerbe und im Dienstleistungspanel, $Z E W$ Wirtschaftsanalysen, vol. 41, Baden-Baden. 
Kaiser, U. (1999). New Technologies and the Demand for Heterogeneous Labor. Centre for European Economic Research, Mannheim, ZEW Discussion Paper, 99/07.

Labeaga, J. (1999). A double-hurdle Rational Addication Model with Heterogeneity: Estimating the Demand for Tobacco. Journal of Econometrics, 93, 49-72.

Liang, K.-Y. and S. L. Zeger (1986). Longitudinal data analysis using generalized linear models. Biometrika 73, 13-22.

Machin, S., and J. van Reenen (1998). Technology and Changes in Skill Structure: Evidence from an International Panel of Industries. Quarterly Journal of Economics, 113(4), 1215-1244.

Maddala, G. S. (1987). Limited Dependent Variable Models Using Panel Data. Journal of Human Resources, 22(3), 307-338.

Maurin, E. and D. Thesmar (1999). Changes in the Demand for Skilled Labor: Technological vs. Organizational Factors. INSEE-CREST, mimeo.

Powell, J. (1984). Least Absolute Deviations Estimation for the Censored Regression Model. Journal of Econometrics, 25, 303-325.

Powell, J. (1986). Symmetrically Trimmed Least Squares Estimation for Tobit Models. Econometrica, 57, 1027-1057.

Robinson, P. and M. Manacorda (1997). Qualifications and the labor Market in Britain 1984 - 94: Skill Biased Change in the Demand for labor or Credentialism. Centre for Economic Performance, London, discussion paper 330.

U.S. Department of Commerce (1998). The Emerging Digital Economy. available at http://www.ecommerce.gov/emerging.htm.

Zeger, S. L., K. Y. Liang, and P. S. Albert (1988). Models for Longitudinal data: A Generalized Estimating Equation Approach. Biometrics, 44, 1049-1060. 


\section{Appendix}

\section{Data Description: Micro Census and Employment Register}

Data for the shift share analysis come from two sources, the employment register of the German Federal Labor Office and the German Labor Force survey (Micro Census). In both data sources, three educational categories can be identified: workers without any vocational training and apprentices are categorized as low-skilled or unskilled; workers with completed apprenticeships are identified as medium-skilled or skilled; and workers with a university or technical university degree are denoted as high-skilled workers.

The first data source, the Federal Labor Office's employment register, contains employment information by educational qualification and by the worker's industry of employment as of 30 June 1999. Covered are all employees who have made social security payments during the 1975-1996 period. For approximately $5 \%$ of employees, the educational qualification is not available. Employment shares by educational category have been calculated as the category's share of total workers (excluding self-employed individuals and workers earning less than DM 630 per month). The data disaggregates the West German economy into 294 sectors. After excluding the agricultural sector, state-run enterprises, as well as non-profit organizations, 269 sectors remain.

The second data source is the German Labor Force Survey. A $70 \%$ public use sample is used for the analysis. The survey is limited to employed workers during the survey reference week in April 1995. The data disaggregates the West German economy into 213 sectors based on, in part, the 1995 NACE classification, and, for 153 sectors, based on previous sector classifications. To unify the sector classification systems across data sources, we corrected for the change of industry classification standards by aggregating the Micro Census data into 20 sector groups. Moreover, repairs of electrical appliances and vehicles were combined with the corresponding manufacturing industries. Employment shares by educational category have been calculated as a proportion of total workers (including self-employees and workers earning less than DM 630 per month). Information on the employee's occupation is available as well. The nine occupations listed in the original data have been regrouped into five occupational areas. 
Table A1: Population-averaged panel Probit models:

Firms' decision to employ university graduates

\begin{tabular}{|c|c|c|c|c|}
\hline & \multicolumn{2}{|c|}{ RE Probit } & \multicolumn{2}{|c|}{ RE Probit, AR(1) } \\
\hline & coeff & t-stat & coeff & t-stat \\
\hline ITQ & 3.51 & 4.04 & 2.86 & 3.56 \\
\hline $\mathrm{ITQ}^{2}$ & -1.51 & -1.38 & -0.84 & -0.80 \\
\hline IQ & 0.01 & 0.14 & -0.02 & -0.20 \\
\hline $\mathrm{IQ}^{2}$ & 0.01 & 0.49 & 0.02 & 0.95 \\
\hline Exporter & 0.23 & 2.40 & 0.23 & 2.76 \\
\hline Ind. group & 0.68 & 5.93 & 0.72 & 6.25 \\
\hline $\mathrm{R} \& \mathrm{D}$ & 0.49 & 2.04 & 0.48 & 1.78 \\
\hline $10 \leq L<20$ & 0.06 & 0.56 & 0.09 & 1.04 \\
\hline $20 \leq L<50$ & 0.14 & 1.14 & 0.15 & 1.30 \\
\hline $50 \leq L<250$ & 0.68 & 4.99 & 0.62 & 4.66 \\
\hline$L \geq 250$ & 1.29 & 7.20 & 1.15 & 7.13 \\
\hline Wholesale trade & -0.28 & -1.66 & -0.24 & -1.42 \\
\hline Retail trade & -0.61 & -3.68 & -0.61 & -3.73 \\
\hline Transport & -0.62 & -3.67 & -0.63 & -3.80 \\
\hline Real estate & -0.22 & -0.97 & -0.22 & -1.00 \\
\hline Software, data processing & 0.89 & 3.27 & 1.02 & 3.70 \\
\hline R\&D labs & 1.19 & 3.63 & 1.34 & 3.62 \\
\hline Business services & 0.91 & 3.73 & 0.90 & 3.54 \\
\hline Other services & -0.43 & -2.36 & -0.41 & -2.30 \\
\hline Community services & 0.37 & 1.22 & 0.35 & 1.17 \\
\hline Constant & -0.18 & -1.12 & -0.35 & -0.39 \\
\hline$\rho$ & \multicolumn{2}{|c|}{0.82} & \multicolumn{2}{|c|}{$0.88 / 0.76$} \\
\hline \multicolumn{5}{|l|}{ Wald test statistics: } \\
\hline $\mathrm{ITQ} \mathrm{ITQ}^{2}=0$ & \multicolumn{2}{|c|}{22.4} & \multicolumn{2}{|c|}{18.8} \\
\hline $\mathrm{ITQ}, \mathrm{ITQ}^{2}, \mathrm{IQ}, \mathrm{IQ}^{2}=0$ & \multicolumn{2}{|c|}{25.2} & \multicolumn{2}{|c|}{22.6} \\
\hline Obs./firms & \multicolumn{2}{|c|}{$2193 / 933$} & \multicolumn{2}{|c|}{$2193 / 933$} \\
\hline \multicolumn{5}{|c|}{$\begin{array}{l}\text { Notes: Dependent variable: indicator of positive employment of uni- } \\
\text { versity graduates. Reference group for sector dummies is bank- } \\
\text { ing/insurance, for size classes size } 1 \text { (less than } 10 \text { workers). L denotes } \\
\text { the number of workers which equals the sum of the three educational } \\
\text { qualification groups. T-statistics are based on robust standard errors. } \\
\text { Source: MIP-S 1994-96, West German firms only. }\end{array}$} \\
\hline
\end{tabular}


Table A2: University graduates' employment share by occupation

\begin{tabular}{|c|c|c|c|c|c|c|}
\hline \multirow[b]{2}{*}{ Occupation } & \multicolumn{3}{|c|}{$\begin{array}{r}\text { University } \\
\text { Grad. Employ- } \\
\text { ment Share, \% }\end{array}$} & \multicolumn{3}{|c|}{$\begin{array}{l}\text { Occupation's } \\
\text { Share of total } \\
\text { Employment, \% }\end{array}$} \\
\hline & '91 & '93 & 95 & '91 & '93 & $' 95$ \\
\hline & \multicolumn{6}{|c|}{ Manufacturing Sector } \\
\hline Production & 1.3 & 1.7 & 2.0 & 49.1 & 48.0 & 47.3 \\
\hline Research, development, and design & 29.6 & 32.7 & 35.1 & 7.9 & 8.0 & 8.1 \\
\hline Trade, sales and repairs & 4.0 & 4.6 & 4.8 & 14.8 & 15.5 & 15.6 \\
\hline Clerical and support staff & 15.8 & 17.4 & 18.0 & 19.9 & 20.4 & 20.7 \\
\hline Other service occupations ${ }^{a}$ & 3.7 & 4.2 & 4.1 & 8.4 & 8.2 & 8.2 \\
\hline \multirow[t]{2}{*}{ All occupations } & 7.0 & 8.0 & 8.6 & 100.0 & 100.0 & 100.0 \\
\hline & \multicolumn{6}{|c|}{ Non-Manufacturing Sector } \\
\hline Production & 2.3 & 2.6 & 2.9 & 13.6 & 13.7 & 13.5 \\
\hline Research, development, and design & 44.7 & 44.7 & 47.0 & 3.9 & 4.2 & 4.3 \\
\hline Trade, sales, and repairs & 3.9 & 4.4 & 4.8 & 22.3 & 21.0 & 21.0 \\
\hline Clerical and support staff & 12.7 & 14.2 & 15.5 & 24.5 & 24.6 & 24.2 \\
\hline Other service occupations ${ }^{a}$ & 22.8 & 23.7 & 24.2 & 35.7 & 36.6 & 36.9 \\
\hline All occupations & 14.2 & 15.3 & 16.1 & 100.0 & 100.0 & 100.0 \\
\hline $\begin{array}{l}\text { Notes: Data for West German privat } \\
{ }^{a} \text { Education, welfare and health servi } \\
\text { Source: German labor Force Survey, }\end{array}$ & $\begin{array}{l}\text { or e } \\
\text { ean } \\
3, \text { a }\end{array}$ & $\begin{array}{l}\text { din } \\
\text { nd }\end{array}$ & icul & $\begin{array}{l}\text { and } \\
\text { ff. } \\
\text { ampl }\end{array}$ & blic $\mathrm{s}$ & \\
\hline
\end{tabular}

